\title{
Promoting Intercultural Communication Competence in the 21st Century: A Case Study in Thai Academic and Social Contexts of Learning and Using EFL
}

\author{
Noparat Tananuraksakul ${ }^{1}$, Suthida Soontornwipat ${ }^{2}$ \\ \{noparat2000@yahoo.com ${ }^{1,}$ Suthida_6@ hotmail.com ${ }^{2}$ \} \\ Rangsit University, Thailand ${ }^{1}$, Huachiew Chalermprakiet University 18/18 Bangna-trad Road, KM \\ 18, Bangplee Samutprakarn 10540, Thailand ${ }^{2}$
}

\begin{abstract}
This paper seeks to propose the way in which Thai university students' intercultural communication competence in the context of learning and using EFL can be promoted through an intercultural course. The primary objective is to examine if students majoring in English and passing the intercultural communication Course can develop the competence or not. Intercultural communication competence was defined with its features, and the Intercultural Communication Course was outlined in order to shed light on this study. Qualitative data collected from twelve English major students who passed the Intercultural Communication Course and continued their academic journey revealed positive outcomes.
\end{abstract}

Keywords: Intercultural Communication, Intercultural Communication Competence, EFL Context.

\section{Introduction}

The current era of globalization has proved to reinforce temporary and permanent human mobility as sojourners and immigrants for specific purposes such as higher education, intermarriage, work and travel. It also increases more opportunities for contact between culturally different others, known as intercultural communication (IC). As argued by Tananuraksakul (2014, p.144), IC is not a simple process since interlocutors must be competent in both linguistic and cultural knowledge so as to create shared meaning and succeed in their communication goals. As such, it is crucial for today's generations from Baby Boomer to $\mathrm{X}$ to $\mathrm{Y}$ to $\mathrm{Z}$ and to $\mathrm{C}$ to attain intercultural communication competence (ICC).

As a matter of fact, Griffith et al. (2016) report that a critical life skill that can predict achievement in the $21^{\text {st }}$ century workforce is ICC because it is an ability most organizations view essential for global missions. In the United States, one of the marketable and native English speaking countries that offer recognized international education along with exchange programs and study abroad experiences, tertiary institutions have thus placed emphasis on ICC and preparation for their students to be competent in IC. University students' ICC learning

\footnotetext{
${ }^{1}$ She is an Assistant Professor in the Department of English and holds a $\mathrm{PhD}$ in Linguistics, Macquarie University, Australia. Her research interest varies from English language teaching to social psychology of global English use to mediated communication and to intercultural communication.
} 
outcome then becomes a crucial measurement for overall institutional achievement. The higher students gain learning outcome in ICC, the more marketable indicator of student is.

It is evident that IC is associated with using foreign languages (Piller, 2007) and English is mostly a common or adopted medium in almost all social contexts (Phan Le Ha, 2005), which inevitably entail non-native and native English speakers. Questions regarding how tertiary students in non-native English speaking countries can learn or acquire ICC and what culture(s) they should learn or acquire arise. Countries where citizens use and learn English as a foreign language (EFL) are norm-dependent rely on the norms originally produced by native English speakers and in general they do not develop or produce a new variety of English (Kachru, 2017). Many countries such as Indonesia, Thailand and Vietnam are countries that fall into this category.

In the case of learning EFL in Thailand, individuals growing up in a monolingual society use Thai, their mother tongue, in and out of the classroom while other languages are foreign to them. On the one hand, they mainly use English for specific purposes such as foreign trading, international diplomacy, gaining access to scientific, technological and literacy materials (Changlek \& Palanukulwong, 2015). On the other hand, they are required to study English from primary to tertiary levels due to its global status. In addition, English has greater linguistic and cultural differences from their mother tongue. Such differences and rare intercultural interactions in daily life make even more difficulty in development of this foreign language competence.

Therefore, intercultural learning in the EFL classroom in Thailand is viewed important. Exposure to intercultural interactions through student mobility (Aba, 2015), assigning intercultural engagement for academic purposes (Tananuraksakul, 2012) and possessing intrinsic or instrumental motivation (Dörnyei \& Clément, 2001) are found to help enhance foreign language learners to develop their linguistic and cultural competencies. Deardorff (2006) supports this notion that language is only a tool individuals use to interact with their interlocutors from culturally diverse backgrounds and develop their competence in IC; it does not guarantee achievement in such interactions. Aba (2015) additionally argues that there is a close relationship with students' competence in IC and foreign language proficiency. Therefore, it is necessary for foreign language teachers to obtain basic insights from cultural anthropology, culture learning and IC so as to promote IC in their classroom through discussions that encourage students to think, interpret and analyze.

Past studies indicate EFL teachers' awareness of interdependence between language and culture as well as the importance of ICC as a key competence in the current century. Promoting IC in their classroom is seen pivotal. For example, in Turkey, Eken (2015) and in Thailand, Cheewasukthaworn and Suwanarak (2017) similarly found that EFL college lecturers were aware of raising IC knowledge in their classroom because it was an effective and beneficial teaching method to improve their English teaching, yet they did not know how or what activities can help enhance their students' ICC. In Poland, Chlopek (2008) proposed intercultural activities in culturally homogeneous classroom of EFL, where teachers "must begin with the students' own cultural background and the cultures that students have direct contact with and then expand from that point until all world cultures have been covered" (p.12). In a Vietnamese context, Tran and Seepho (2016) integrated intercultural content into an English communicative language course in order to explore EFL learners' (from primary school to university) attitudes towards intercultural communicative language teaching (ICLT) and their ICC development. The preliminary results indicated positive directions.

ICC as an outcome of intercultural learning can supplement the development of EFL students' linguistic ability (Davis, Cho \& Hagenson, 2015) and seems to be a good way to 
promote tolerance, acceptance, understanding, and respect of culturally different others (Chlopek, 2008). However, there is no study into promoting ICC through teaching IC as a separate course to English major students. This paper seeks to propose the way in which Thai university students' ICC in the context of learning and using EFL can be promoted through an intercultural course. The primary objective is to examine if students majoring in English and passing the IC Course can develop ICC or not.

\section{Promoting ICC In Thai Academic And Social Contexts Of Learning And Using EFL}

In Thailand, Bennui and Hashim (2014) found in their study that Thai people prioritize British and American English rather than other English varieties. In fact, they are the target language norms for teaching EFL in other contexts (Wornyo \& Klu, 2018) so as to create mutual intelligibility for the purpose of International communication (Farrell \& Martin, 2009). In addition, language and culture are seen intertwined. British and American cultures should thus be taught to EFL students without ignorance of learning other native and non-native English speaking backgrounds, especially the ones students have more direct contact.

In line with Hismanoglu's (2011) argument about the natural consequence of globalization that renders IC and ICC essential in the field of foreign language teaching, the Department of English, Faculty of Liber Arts at Huachiew Chalermprakiet University offers the IC Course as one of the core courses to English major students. The researcher was assigned to instruct this course in 2018 during January and May. The course was designed to help students: 1) develop cultural understandings, positive attitudes toward cultural differences, and IC skills needed to function appropriately and effectively within diverse societies; 2) explain the nature of language, principles governing the use of language, and culture reflected in language; 3 ) analyze and explain the problems that occur in IC; 4) identify or provide some solutions to problems in IC; and 5) communicate effectively in IC.

Since English has earned its global status and has reinforced IC in many contexts, which involve both non-native and native English speaking interactants, it is appropriate to study these two areas from a perspective of anthropology, the study of humankind that helps increase our understanding of ourselves and of each other. As a result, 15 weekly teaching plans for this course are outlined from a perspective of anthropology and cross-cultural communication (Tananuraksakul, 2017). Each week students are encouraged to participate in group discussion and compare their native culture to others, evaluating and interpreting the comparative results. The understanding is expected to render them culturally relativistic rather than ethnocentric. The former views all cultures as unique values; the latter considers their own culture better than others'. The following shows some examples of weekly teaching plans and topics of students' presentations pre-approved by the researcher:

Week One: Introduce some arguments of the spread of English and its global status as well as a framework from anthropological perspective. The introduction will help students understand how English has spread throughout the globe and become recognized worldwide. They will also understand use of English in different contexts and be aware of language barriers and psychological impacts that they may experience when stepping into a context of IC and crosscultural communication. 
Sample Discussion Questions: 1) Do you personally think English will still dominate the world in the next decades? Give your reasons why or why not. 2) In the contexts of English as a lingua franca, who do you think has the most advantage in communication and why do you think so? 3) What would be barriers when people from culturally diverse backgrounds communicate in 'world Englishes'?

Week Two: Introduce the definition of culture, characteristics of culture, influence of culture over communication and thought patterns. Some of these aspects of culture, such as beliefs, cultural values and patterns of thought are of particular essence for learners of EFL to be aware of and understand. The reason is that they will be able to analyze and interpret more positively towards culturally different others' ways of thinking and behaving that are not easy to understand.

Sample Discussion Questions: 1) In what way does culture affect your ways of thinking? 2) How does globalization affect you culturally and/or socially? 3) If you are awarded a scholarship to pursue your higher education in an English-speaking country, what types of barriers do you think you will be facing? Explain how and why. 4) If you work with a British or an American in a multinational company, explain how different thought patterns between you and the British or the American may cause you difficulty.

Week Three: Introduce a brief history of making of the UK and how it transmits to core British values that characterize "Britishness". The values are defined from perspectives of the governments and academics. These core cultural values will assist students to understand more of the British ways of thinking and behaving.

Sample Discussion Questions: 1) Do you think there are some other values British people may live by? 2) Have you had trouble in understanding a British's behavior? If yes, can you explain by now why he or she behaved that way? What will you react or respond if you have the same experience? 3) Due to the values of achievement, choices and competition, do you think British people also value privacy, time and adherences to rules and regulations? Explain why or why not.

Week Four: Introduce the definition of lifestyle, which is part of an external aspect of culture. It then explores common leisure activities the British enjoy. Students will understand how the activities reflect their ways of living.

Sample Discussion Questions: 1) What do you think have impacts on British people's ways of life? Do you think its geography, climate and religion are the impacts? 2) Lifestyle is expressed in both work and leisure behavior patterns and on an individual basis in activities, attitudes, interests, opinions, values, and allocation of income. Can you explain how British lifestyle reflects on the people's identity? 3) Do you think there are other kinds of sports the British also play? Describe those sports. 4) Does going to a pub convey parts of the life in your country? Explain how it conveys.

Week Five: Address some of the social aspects of the UK, which reflects on the society as a whole and how its members live together, and also some other social aspects that have recently had a great impact on the British society.

Sample Discussion Questions: 1) Do you personally think the UK is a good place to live? Explain why or why not. 2) Are there any aspects of the British society similar to or different from any of you? Explain how it is similar or different. 3) Have any of those similar aspects influenced over the society you live? Explain how they have influenced so. 4) If you have an 
opportunity to visit the UK, how would you face a language barrier there? 5) Why do you think the UK is a developed country?

Week Six: Introduce traditional holidays that have been influenced by the predominant religion and have been celebrated throughout the UK, festivals and traditions that the British enjoy celebrating, and some important customs that are British common rules. The festivals, traditions and customs reflect on the UK identity.

Sample Discussion Questions: 1) Are there any British customs you think people in your country should adopt? Give reasons why. 2) Have any British customs and traditions influenced over your culture? Explain how they have influenced so. 3) Are there any festivals and holidays in your country influenced by religions? 4) What are those festivals and holidays? How do the people in your country celebrate them? 5) Do you share any superstitions and taboos in common with the British? Explain what those are. 6) Do you find any of British festivals, holidays, common important customs and superstitions bizarre? Explain why or why not.

Week Seven: Introduce a brief history of making of the US along with basic cultural values and beliefs that the mainstream in this country lives by. These basic values and beliefs will help students understand more of the Americans' ways of thinking and behaving in general.

Sample Discussion Questions: 1) Since Americans are hard workers in nature and enjoy freedom, dependence on themselves and comfortable lives, do you think there are some other cultural values they may live by? Explain what they are. 2) Why do you think America has attracted many people around the world to immigrate to this country? 3) If you immigrate to the US, will you find it difficult for you to live there? Explain why or why not. 4) Which of the basic cultural values and beliefs do you appreciate? Explain why. 5) Which of the basic cultural values and beliefs have misled people in your country to adopt?

Students' Presentations: 1) non-verbal communication in different cultures; 2) cultural values and beliefs in European countries; 3) Hispanic cultural values and beliefs; 4) cultural values and beliefs in ASEAN countries; 5) the notion of ICC; 6) students' intercultural interview project.

\section{Definition Of Key Term}

In order to shed light on the study whether the IC Course can help promote English major students' ICC, in this study ICC refers to one's ability to interact effectively and appropriately with culturally different others in a foreign language (Byram, 2000) that is English. The concept of effective and appropriate interactions in ICC comports with Spitzberg and Cupach's (1989) general communication competence in that an individual is not only effective communicator who can succeed in his or her goals but also an appropriate communicator who can exhibit accepted and expected behaviors in a social situation. Being an effective and appropriate communicator with culturally different others requires English language competence and intercultural competence.

In this study, features of both language and intercultural competences are adapted from Tran's (2015, p.30) doctoral study. The former includes linguistic, sociolinguistic and discourse competences. Since the students are senior and major in English, they are assumed to have different levels of English competence to interact with culturally different others. The 
latter are attitude, knowledge, awareness and skills. Attitude refers to positive feelings and thinking about cultural differences and culturally different others without judging others based on one's own cultural standards, known as cultural relativism. Due to the EFL context itself, enthusiasm for learning about other cultures and confidence in IC engagement should characterize EFL students' ICC. Knowledge is cultural aspects one has learned or acquired while awareness refers to knowledge that cultural differences exist. Skills are one's ability to analyze and explain the problems that occur in IC as well as identify or provide some solutions to problems in IC. All of these intercultural features assist individuals to exhibit their behaviors appropriately in IC.

\section{Procedures Of The Study}

The present study started with participant selection and recruitment. The target group was those English major students enrolled in the IC Course with the researcher during January and May in 2018. They were in their third year during the time of study, but during the recruitment they were in their fourth year voluntarily participated in virtual interviews through either Facebook Messenger or Line during February 1-11, 2019. The interview data were then translated into English and grouped into common categories or themes.

A number of 12 students answered these interview questions in Thai that sought to find out their ICC: 1) what have you learned from the IC course 2) how has the knowledge you learned helped you equip with communication with culturally different others? 3) Have you had enthusiasm for learning more about other cultures? 4) Do you gain more confidence in intercultural contact? Why or why not? 5) Have you learned that every culture can be different and that none of the culture is better than others?

\section{Findings And Discussion}

The virtual interviews from 12 participants were commonly grouped into three themes reflecting ICC they developed through the IC Course. Theme one is about knowledge and awareness of cultural differences; the following themes are attitudes and skills.

\section{Theme One: Knowledge and Awareness of Cultural Differences}

Despite the length (9 months) almost all students finished the IC Course, they still remember what they have learned from the class, building up their background knowledge or schema. Most students referred their schemata to the phenomenon of English use in many contexts which can be more understood through Kachru's (2017) argument on the term 'World Englishes', which he coined in the 1980s. The term has been the most influential model containing three concentric circles and descriptions regarding the use and spread of English. First, the Inner Circle is the world of English historically spoken as a mother tongue or English as a native language (ENL). Australia, Canada, New Zealand, the United Kingdom and the United States fit into this group. Second, the Outer Circle refers to a large number of formerly colonized territories including Bangladesh, India, Malaysia, Nigeria, Sri Lanka, Singapore and the Philippines, and people in these countries use English as a second language (ESL). They provide norm-developing varieties of English, a localized norm that has well established linguistic and cultural identity. Third, the Expanding Circle regards EFL societies. 
English in this particular Circle has become the most popular foreign language taught in the school systems (Bolton. 2006: 299).

Two students particularly were able to draw these schemata when taking other classes in different semester. Students 1 and 9 shared in parallel that they could apply how English globally spread in the forms of three Concentric Circles and the concepts of World Englishes to the Principles in Teaching English Course. Student 1 explicitly stated that the effects of IC in World Englishes also helped her understand this subject better. During her study of the English for Tourism Course, the IC Course also enabled her to perceive that:

understanding cultural differences between a host and guests from other countries allows the host to behave in a way appropriate to the guests and this will lead to an impressive visit to Thailand. Those aspects of culture particularly include cautions of non-verbal communication usage, i.e. gestures, postures and proper distance during interactions.

Students 2 and 5 realized why people from different nations have imbalances of English competences. Student 2 additionally explained that "I learned that some countries were colonized by America and Britain and forced to use English ... That explains why people from the Outer Circle can speak English more fluently than the ones from the Expanding Circle". Students 7 and 12 learned more about "a variety of English... different English accents from the three Circles". The latter considered being colonized had a good advantage in acquiring English.

Apart from the phenomenon and spread of English use, many students also referred their schemata to cultural values, beliefs and thought patterns. Student 2 recalled the differences in thinking and perceiving the world between people from high context culture and low context culture and said:

I learned from this class why individuals from high context culture tend to communicate indirectly as compared to low context culture... passive learners...why Americans are more opinionated, reliant on themselves than Asian people who tend to go around the bush in order to get things done... it's about differences in cultural values and thought patterns. In general, the Westerners are individualistic and embrace ambiguity tolerance while Asians are collectivistic and prefer to avoid uncertainty. I also learn that the Brits are a bit more like Thais in terms of indirect communication as they value politeness and courtesy.

Students 6 and 8 "learned about other nationals' cultures". The latter elaborates on this "I learned that differences in cultural values, religious beliefs and lifestyles cause people from different nations to think and behave differently. For Student 4, "each nation has its own customs and beliefs, and in order to work together successfully we need to understand the differences".

Students 2 and 3 shared the same experience in analyzing cultural differences as they said "questions for discussion shaped up my thinking and analysis better". The former elaborated that "I learned different angles about the analysis from my classmates as well". Student 10 realized that "effective communication with culturally different others requires competences in both language and culture". 
The analytical findings show that 11 students learned about and were aware of different aspects of cultures and the way in which English governed the world, suggesting that they developed cultural understanding and nature use of English in different social contexts of ENL, ESL, EFL and ELF. These suggestions further imply that in the context of learning and using EFL, the IC Course can promote students' ICC.

\section{Theme Two: Attitudes}

Almost all students earn positive attitudes after taking the IC Course since they have more enthusiasm for learning about other cultures and confidence in IC engagement. They also practice cultural relativism. Student 10 "felt more enthusiastic to learn about other cultures because he wanted to succeed in IC, and intercultural learning allowed him to see the world in a wider perspective". Student 1 explained in detail:

I am more enthusiastic to learn about various cultural aspects because all cultures are shaped by history, geography, politics and government, so judging others based on our own standard or culture is not suggested. I have more curiosity for cultural learning in the real world of workforce. One thing I can't forget is about culture being dynamic and it is so true that today's world has kept changing. If I ignore this fact, I will be outdated in many ways.

It appears that knowledge and awareness of cultural differences assist students in enhancement of self-confidence. Student 8 particularly mentioned that "as I don't have any bias of cultural differences, I feel confident to communicate with culturally different others". I am also confident in IC. Although Student 9 could not speak English fluently, she thought she felt more confident as she used the language more in the real world. Students 3, 4, 5 and 7 similarly said "I felt more confident to communicate with culturally different others because I am aware of their core cultural values and beliefs... what is appropriate or inappropriate". For Student 1, she found she gained confidence during the job training. Her job assignments were to correspond and meet with foreign investors and service foreign customers. She further explained that "I found myself to be more confident because I have cultural knowledge and understand that no single culture exists in this world and that each is unique".

Some other students gained confidence through the interview assignment. Student 6 stated "I got the courage to initiate interviews with foreigners". Students 2, 11 and 12 thought "I gain more confidence in speaking in English due to the interview assignment. Student 2 elaborated "at first, I was bashful to interview foreigners. When I started the interview, I gained the courage and enjoyed talking in English more." For Student 11, "once I was successful with the first interview, I felt proud of myself and looked forward to interacting with other foreigners". For Student 12, as a part of the course assignment:

I had a chance to interview someone from Japan who had unique characters ... everyone could tell this person is from Japan. I became interested in Japanese culture as I wanted to learn more about its non-verbal communication... why it's a taboo to point a finger. I think understanding culturally different others helped me gain confidence in IC. Plus, I could see that the interviewee was willing to talk to me and welcomed my questions.

Student 10 is the only person who thinks he still lacks confidence despite his enthusiasm for intercultural learning. He said "for one thing I am bashful, have no courage to speak in 
English. In fact, I'm afraid of face loss". His perceptions align with Tananuraksakul's (2012, p. 90-91) study into Thai EFL learners' encounters of IC in Thailand particularly their security and dignity that face and facework were key behavioral patterns in Thai culture. In fact, Student 10 experienced communication apprehension, normally stemming from shyness. The apprehensive feeling in turn affected his risk-taking and self-confidence.

Knowledge and awareness of cultural differences also assist students in enhancement of cultural relativism. Student 1 thinks:

every culture is unique, so there's no better culture than others. When I went out for lunch with a French friend, both of us had the same dish of chicken with rice served with a bowl soup. The way we had the dish differed. I ate rice and chicken alternatively with the soup while she finished her soup first. I noticed how she looked at me with amusing face.

Student 4 shared that "the differences convey beauty that stimulates me to learn more about other cultures". Cultural differences should be acceptable for IC." For Student 7, "every culture is unique, none of culture is better than others." Student 2 explicitly shared that:

this class helps me understand culturally different others better. None of culture is right or wrong. Everyone is brought up according to his/her own culture transmitted from generations. I have more positive thinking about foreigners' different communication behaviors".

Student 3 said "I had more interest in learning about similarities and differences between us and them because understanding how others think and behave is the way to show respect and this makes me confident to interact with foreigners". Student 9 thought she felt more enthusiastic to learn about foreign cultures since awareness of cultural differences was seen a tool to help her adjust her life in the current era. She exemplified a personal situation at a McDonald's in a foreign land. "Immediately, I could see the physical setting, the atmosphere and condiments provided differ from what we had back home. The local people talked loudly in their group, unlike ours. At first, I thought they were rude but I realized that was the way it was. We behaved differently and that should be accepted in that manner".

The analytical findings above suggest that the students developed positive attitudes toward cultural differences and culturally different others without judging others based on their own cultural standards because four students expressed their enthusiasm for further intercultural learning, 11 students felt more confident to engage in IC, and six students exercised cultural relativism. The analysis can further implies in accordance with Chlopek (2008) that the IC Course can be a good way to promote not only EFL learners' positive attitudes toward cultural differences and culturally different others but also their tolerance, acceptance, understanding and respect of culturally different others. While enthusiasm and confidence characterize EFL learners' positive attitudes, the notion of face and facework as well as communication apprehension can impair EFL learners' confidence.

\section{Theme Three: Skills}

Only Student 2 manifests her IC skills since she was the only person who had IC encounters during her job training with a multicultural company in Thailand. She shared explicitly: 
I am able to apply the cultural knowledge I learned in this subject in my daily life and workforce. During my cooperative education last year, I had to interact with foreign executives and international customers who used car rent services at the company I had the job training in Thailand. [On the one hand] I found that I needed to adjust to IC within the organization and cope with the customers' cultural and linguistic diversity so as to ensure intelligibility. There was another French trainee who clearly relied on her own idea and was unable to understand the notion of respect for seniority in Thai culture. [On the other hand] I found myself to be more confident because I have cultural knowledge and understand that no single culture exists in this world and that each is unique. With this thinking in mind, I am able to accept, adjust and behave in an appropriate way although it took me some time. Many customers asked about my name after I finished my training. Personally, I think this subject is very useful and students should prioritize it because we live in the perceived shrinking world.

The findings reveal one student who appeared to develop IC skills because she was able to analyze and explain the IC problems that occurred in the company as well as identify or provide some solutions to the IC problems. Adjusting herself to the new environment was her solution. This analytical finding was parallel with research outcomes of Aba's (2015) and Tananuraksakul's (2012) in that exposure to IC could develop EFL learners' ICC. The analysis further implies that the IC Course can promote EFL learners' ICC.

\section{Conclusion}

This qualitative study by means of virtual interviews on Facebook Messenger and Line seeks to examine whether the IC Course offered to English major students of Huachiew Chalermprapkiet University can promote their ICC. The analytical results garnered from twelve students were commonly grouped into three themes suggested that they developed 1) cultural understanding and nature use of English in different social contexts of ENL, ESL, EFL and ELF; 2) positive attitudes toward cultural differences and culturally different others without judging others based on their own cultural standards; and 3) skills to analyze IC problems and identify solutions to the IC problems. These suggestions can further imply that in the context of learning and using EFL, the IC Course can promote: 1) English major students' ICC because they appear to attain abilities to interact effectively and appropriately with culturally different others (Byram, 2000) in English; and 2) their positive attitudes toward not only cultural differences and culturally different others but also their tolerance, acceptance, understanding and respect of culturally different others. Enthusiasm and confidence characterize EFL learners' positive attitudes, but the notion of face and facework as well as communication apprehension can impair their confidence.

Although the study is limited by its nature of qualitative research approach that involves a small number of participants, the empirical outcomes provide insights and directions for future research. A longitudinal study with students who pass the IC Course and experience more in IC is recommended. Another recommendation includes a quantitative survey. 


\section{Adknowledgements}

I would like to express my gratitude to all of the participants who spared their precious time for sharing their views of learning the Intercultural Communication Course with me and their experiences in intercultural communication in the real world.

\section{References}

[1]. Aba, D. (2015). Towards an intercultural communication competence tool for academic mobility purposes. Journal of Intercultural Communication, Issue 39.

[2]. Bennui, P. \& Hashim, A. (2014). English in Thailand: Development of English in a nonpostcolonial context. Asian Englishes, 16(3), 209-228.

[3]. Bolton, K. (2006). Varieties of World Englishes. In B. B. Kachru, Y. Kachru, C. L. Nelson. (Eds.), The handbook of World Englishes (pp. 289-312). Oxford: Blackwell Publishing.

[4]. Byram, M. (2000). Assessing intercultural competence in language teaching. Sprogforum, 18(6), 813.

[5]. Changlek, A. \& Palanukulwong, T. (2015). Motivation and grit: Predictors of language learning achievement. International (Humanities, Social Sciences and Arts), 8(4), 23-38.

[6]. Cheewasukthaworn, K. \& Suwanarak, K. (2017). Exploring Thai EFL teachers' perceptions of how intercultural communicative competence is important for their students. PASAA: Journal of Language Teaching and Learning in Thailand, 54, 177-204.

[7]. Chlopek, Z. (2008). The intercultural approach to EFL teaching and learning. English Teaching Forum, Number 4. Retrieved from https://americanenglish.state.gov/files/ae/resource_files/08-464-c.pdf

[8]. Davis, N., Cho, M.O. \& Hagenson, L. (2005). Intercultural competence and the role of technology in teacher education. Contemporary Issues in Technology and Teacher Education, 4(4), 1-9.

[9]. Deardorff, D. K. (2006). The identification and assessment of intercultural competence as a student outcome of internationalization. Journal of Studies in International Education, 241-266.

[10]. Dörnyei, Z. \& Clément, R. (2001). Motivational characteristics of learning different target languages: Results of a nationwide survey. In Z. Dörnyei and R. Schmidt (Eds.). Motivation and second language acquisition (pp.399-432). Honolulu, HI: University of Hawaii Press.

[11]. Eken, D.T. (2015). Intercultural communicative competence: EFL teachers' beliefs and practices. Journal of Teaching and Education, 04(03), 63-71.

[12]. Farrell, T.S.C. \& Martin, S. (2009). To teach standard English or world Englishes? A balanced approach to instruction. English Teaching Forum, 2, 2-7.

[13]. Griffith, R.L., Wolfeld, L., Armon, B.K., Rios, J. \& Liu, O.L. (2016). Assessing intercultural competence in higher education: Existing research and future directions. ETS Research Report No. RR-16-25.

[14]. Hismanoglu, M. (2011). An investigation of ELT students' intercultural communicative competence in relation to linguistic proficiency, overseas experience and formal instruction. International Journal of Intercultural Relations, 35(6), 805-817.

[15]. Kachru, B.B. (2017). World Englishes and culture wars. Cambridge: Cambridge University Press.

[16]. Phan Le Ha. (2005). Toward a critical notion of appropriation of English as an international language. Asian EFL Journal 7 (3): 34-46.

[17]. Piller, I. (2007). Linguistics and intercultural communication. Language and Linguistics Compass, 208-226.

[18]. Spitzberg, B. H. \& Cupach, W. R. (1989). Handbook of interpersonal competence research. New York, NY: Springer-Verlag.

[19]. Tananuraksakul, N. (2012). Psychological and linguistic identities in a Thai EFL/ELF context. International Journal of Language Studies, 6(3), 81-98.

[20]. Tananuraksakul, N. (2014). Interrelationship between linguistic identity, perception, psychological wellbeing and context: Use of global English in an Australian context. Journal of Applied Linguistics, 6.2, 143-163. 
[21]. Tananuraksakul, N. (2017). Cultures of English-Speaking Peoples: An Anthropological Perspective. Samutprakarn, Thailand: Huachiew Chalermprakiet University Press.

[22]. Tran, T. Q. \& Seepho, S. (2016). EFL learners' attitudes toward intercultural communicative language teaching and their intercultural communicative competence development. Journal of English Studies, 11, 1-40.

[23]. Wornyo, A.A. \& Klu, E. K. (2018). Teaching academic writing skills using intercultural rhetoric approach: The criticisms and intercultural communication. Journal of Intercultural Communication, 48. 